\title{
Can Microfinance Reduce Portfolio Volatility?
}

\author{
Nicolas Krauss ${ }^{a}$ and Ingo Walter ${ }^{b}$ \\ ${ }^{a}$ Department of Politics, New York University, New York, NY10012, USA \\ ${ }^{b}$ Stern School of Business, New York University, New York, NY10012, USA
}

This Version: 18 February, 2008

\begin{abstract}
Microfinance is arguably one of the most effective techniques for poverty alleviation in developing countries. Although traditionally supported by nongovernmental organizations and socially-oriented investors, microfinance institutions (MFIs) have increasingly demonstrated their value on a stand-alone basis, typically exhibiting low default rates combined with attractive returns and growth, encouraging greater commercial involvement. This paper addresses a related issue - whether microfinance shows low correlation with international and domestic market performance measures. If so, it could form the empirical basis for MFI access to capital markets and performance-driven investors in their search for efficient portfolios. Our empirical tests do not show any exposure of microfinance institutions to global capital markets, but significant exposure regarding domestic GDP, suggesting that microfinance investments may have useful portfolio diversification value for international investors, not for domestic investors lacking significant country risk diversification options.
\end{abstract}

Keywords: microfinance, poverty alleviation, systemic risk

JEL Classification: G21, O16.

*We are grateful to David Denoon, William Greene, Richard Moxon, Peter Johnson, Brad Swanson, Roger Frank, Paul Wachtel, Adrian Gonzalez and Hans-Martin v. Gaudecker to helpful comments on various drafts of this paper. All errors are our own. 
Microfinance, traditionally supported by aid agencies and non-profit entities, has become an important tool in the alleviation of poverty in developing countries. In recent years, the role of non-profit lenders and investors in microfinance institutions (MFIs) has declined as broader sources of funding have been accessed, including client deposits of bank-related micro-lenders, refinancings via interbank deposits and commercial loans, and raising funds in capital markets.

Apart from the social benefit associated with an increase of available funds, the argument for commercialization of microfinance is that the risk of financial loss - comprising the likelihood of default, the loss given default (LGD), and present value of expected recoveries (ER) - tends to be low relative to the returns, and that the risk-adjusted total returns on microfinance exhibit low correlations to those of other available asset classes, thereby presenting investors with an attractive opportunity for portfolio diversification.

This paper focuses on the question whether the value of financial exposure to MFIs in fact exhibits low correlations with the value of broad asset categories available to commercial investors, both locally and globally. If the finding is that the correlations are low, then it is possible to argue that microfinance investments represent a potentially useful asset allocation technique for fund managers seeking greater portfolio efficiency. Such a finding would also form the basis for improved access for MFI funding through securitization issues distributed to global institutional asset pools such as insurance companies, trusts and pension funds.

Section 1 of this paper considers the institutional transformation of microfinance from donor-driven non-governmental organizations (NGOs) towards market-driven financial institutions - requiring adaptation of their sources of financing to commercial terms while at the same time avoiding mission-drift away from the social goal of poverty-alleviation. Section 2 presents an empirical analysis of the systemic risk of microfinance institutions, regressing key fundamental parameters and ratios of the leading MFIs against the S\&P 500, MSCl Global and MSCl Emerging Markets indexes (as proxies 
for global market risk) as well as against domestic GDP (as proxy for domestic market risk). In addition to analyzing the absolute market risk associated with microfinance, we also consider the relative market risk in this section, comparing MFIs to other potential emerging market investments - equities of listed emerging market institutions (EMIs) and equities of listed emerging market commercial banks (EMCBs). Since available data do not yet permit solid empirical stress-testing, we link our results to case study-based evidence on the performance of MFIs in times of domestic financial and macroeconomic adversity. Section 3 attempts to explain the results observed on a qualitative basis and suggests how these findings may change as the microfinance industry matures. Section 4 presents our conclusions.

\section{Evolution of Microfinance}

Approximately 10,000 MFls have evolved worldwide over some three decades - in an amalgam of non-governmental organizations (NGOs), commercial banking entities, credit unions, cooperatives and finance companies - serving some 40 million clients worldwide. Total loan portfolios of MFIs in mid-2006 amounted to about $\$ 17$ billion, with the potential to grow to $\$ 250$ to $\$ 300$ billion in the foreseeable future [Ehrbeck, 2006]. Estimates of MFI annual growth rates range from $15 \%$ to $30 \%$, thus suggesting a demand of somewhere between $\$ 2.5$ billion and $\$ 5$ billion for additional portfolio capital each year, with $\$ 300$ million to $\$ 400$ million in additional equity required to support such lending, an estimate that could well turn out to be conservative [Callaghan, Gonzalez, Maurice, Novak, 2007]. ${ }^{1}$ A 2004 survey of over 144 MFIs indicated that scarce donor funding has been the principal factor in limiting growth. [Consultative Group to Assist the Poor, 2004] Consequently, many MFIs have transformed themselves from mission-driven, often inefficient NGOs into regulated financial institutions partially or entirely funded by private capital. Apart from encouraging better management, coherent reporting standards, credit ratings and formation of viable industry associations,

\footnotetext{
${ }^{1}$ The median loan portfolio growth rate in our sample is $37 \%$
} 
regulation opened new financing alternatives for MFIs, including deposit-taking and the issuance of domestic and international securities.

Deposits are generally the cheapest and most stable form of financing for MFIs that have acquired banking licenses, ${ }^{2}$ although the local savings pool is often constrained. Enabling MFIs to additionally access capital markets allows them to satisfy local demand and finance growth. The longer maturity of capital market financing also strengthens the financial structure of MFIs, and may render them less vulnerable to external factors such as currency devaluations, bank runs and macroeconomic crises. ${ }^{3}$ Moreover, capital markets can significantly increase the efficiency of financial intermediation, further reducing the financing costs of MFIs. ${ }^{4}$ Since registering as a financial institution means adhering to more rigorous liquidity, capital adequacy and reporting standards, it does not make sense for all MFIs. This is especially true for institutions located in regions where operating costs are high and the local savings pool is small, or where governments set caps on lending rates for regulated financial entities.

A number of MFIs have taken advantage of capital markets as an attractive financing alternative. The first was Banco Compartamos in Mexico, which undertook a \$68 million local-currency microfinance bond issue in 2002 and subsequently listed on the Mexican Stock Exchange in a highly successful IPO in April 2007. The first international microfinance-backed bond issue, a $\$ 40$ million securitization of cross-border loans to nine MFIs in Latin America, Eastern Europe and Southeast Asia, was structured by Developing World Markets in 2004. Another $\$ 60$ million collateralized debt obligation (CDO) in 2006 by the same firm involved 26 widely dispersed MFIs that had an average annual loan portfolio growth rate of $30 \%$, a return on equity in excess of $20 \%$, and a portfolio-at-risk level (late payment exceeding 30 days) of $2.5 \%$.

\footnotetext{
${ }^{2}$ As of December 2003, the average cost of funds for deposit-taking MFIs was only $6.7 \%$, compared to $10.1 \%$ for the others [von Stauffenberg, 2004]

${ }^{3}$ Issuing bonds not only diversifies, but also increases the avg. maturity of debt. Fundación Women's World Banking (WWB), an NGO MFI in Colombia, reports that after it starting issuing bonds, the average maturity of its liabilities increased from 2.2 to 3.2 years [Accion, 2006] ${ }^{4}$ For example, Fundación WWB reported that its average financing costs decreased after the issuance of bonds by 360 basis points. [Accion, 2006]
} 
[Swanson, 2007]. A May 2007 Morgan Stanley microfinance issue worth $\$ 108$ million was oversubscribed. Standard \& Poor's announced plans in 2007 to begin rating MFIs, which would make microfinance-backed securities eligible for investment by pension funds.

What makes microfinance potentially compelling from a commercial perspective are low default rates, which for MFIs tend to fall between $1 \%$ and $3 \%{ }^{5}$ [Easton, 2005], combined with potentially low systemic risk, impressive growth rates and reasonable returns. The median ROE over the nine years covered by our dataset (1998-2006) - which can be regarded as a collection of the leading $325 \mathrm{MFIs}$ - was $5.8 \%$, with a median loan portfolio growth rate of $37 \%$ annually (the corresponding figure for net operating income growth was 28.5\%). In a recent study, Littlefield and Holtman [2005] find that worldwide, the top MFIs are nearly twice as profitable as the leading commercial banks in their local environments. An IFC panel study covering five banks in OECD countries and six emerging market banks found that SME portfolios generate higher ROA than total bank portfolios - four out of five banks noted higher portfolio and income growth for the SME segment than for the overall bank. ${ }^{6}$

MFI transaction costs are much higher than in traditional commercial banking, but the high marginal productivity of capital expenditures undertaken by microfinance borrowers appears to justify materially higher interest rates than typically apply in commercial lending. ${ }^{7}$ Survey-based studies conducted in India, Kenya and the Philippines found that the average annual return on investments by microbusinesses ranged between 117 and 847 percent [Consultative Group to Assist the Poor, 2002]. Experience in various developing countries generally suggests that microcredit recipients are capable of paying interest rates that allow MFIs to more than cover their high lending costs. [Consultative Group to Assist the Poor, 2004]

\footnotetext{
${ }^{5}$ However, these values potentially suffer from "survivorship bias". The median value for the 325 MFIs used in our sample is $2.5 \%$

${ }^{6}$ MicroBanking Bulletin, Issue 15 (Autumn 2007)

${ }^{7}$ the annualized percentage rate of MFI loans is usually between $20 \%$ and $60 \%$
} 
Despite such evidence - together with significant progress by MFIs in terms of improved operating efficiency, establishment of industry standards and the beginnings of capital market access - microfinance is only beginning to compete with other asset classes for the attention of institutional asset managers. Investors appear to perceive microfinance as excessively risky relative to the returns it generates, partially due to a lack of viable foreign exchange hedges, absence of a solid track record, poor reporting standards, heterogeneous products and inadequate liquidity. This is also true for dedicated microfinance funds, which generally invest in privately-placed, relatively illiquid assets and are therefore unable to report pricing on a daily basis. Such problems have so far generally disqualified microfinance as an investible asset class for most mutual funds and other institutional investors. ${ }^{8}$

\section{The Risk Profile of Microfinance Institutions}

In a working paper [Krauss and Walter, 2006], we conducted the first empirical analysis of panel data covering large numbers of MFIs in order to investigate the systemic risk of microfinance. Our tentative findings, which were based on a smaller dataset of much lower quality than the present paper and used only EMCBs as a benchmark, suggested that MFIs exhibit low correlations to international capital markets, mainly due to a lower asset exposure. The findings also suggested low correlation to domestic GDP due lower income and profitability exposure. A second empirical study, conducted by Adrian Gonzales [2007] examined 639 MFIs in 88 countries reporting data to the MIX ${ }^{9}$ mainly in the period 1999-2005. It used the same database as the present study (restricted Microbanking Bulletin data), but included almost twice the number of MFIs - we exclude all MFIs that reported less than 3 consecutive years of data. The Gonzales study is limited to the analysis of the impact of

\footnotetext{
${ }^{8}$ However, some of the more sophisticated funds actually have created pricing models which are in line with SEC regulations.

${ }^{9}$ Microfinance Information eXchange (MIX), is a not-for-profit private organization supported by CGAP, the Citigroup Foundation, the Open Society Institute, the Rockdale Foundation, and other private foundations.
} 
domestic macroeconomic shocks on portfolio quality. It does not measure global market risk or incorporate other factors such as income, profitability or asset growth, nor does it include other asset classes as benchmarks. After controlling for MFI and country characteristics, Gonzales does not find any evidence suggesting a positive and statistically significant relationship between MFI performance and changes in GNI per capita, suggesting substantial resilience of MFIs to macroeconomic shocks. Other significant research in this field is confined to several case-studies analyzing the performance of a few selected MFIs in times of macroeconomic distress. ${ }^{10}$

The standard approach to analyzing the risk of an asset class is to calculate the historical market beta - i.e. to regress the returns of an asset class over a certain period of time against the returns of a benchmark index. This approach is only possible for publicly traded financial institutions capable of being marked-to-market and generating a dataset with a sufficiently large number of observations. MFIs are virtually all non-listed companies with no mark-to-market valuation, so it is not possible to obtain betas from historical securities prices.

A second approach is estimation of a fundamental beta - analyzing the types of businesses in which a firm operates, identifying publicly traded firms in those businesses, and obtaining their regression betas as a proxy. This is likewise not possible in the case of MFIs, since microfinance is an emerging asset class with no peer group of listed firms. ${ }^{11}$

Consequently, the only feasible approach in the case of microfinance institutions requires reliance on accounting earnings: Changes in earnings of a firm can be related to changes in earnings of the market over a comparable period to arrive at an estimate of the accounting beta. This approach admittedly suffers from biases due to earnings-smoothing by firms, and can be influenced by non-operating factors such as changes in depreciation or inventory

\footnotetext{
${ }^{10}$ Section 3 of this paper reviews the available case-study evidence.

${ }^{11}$ As we demonstrate in section 3, using emerging market commercial banks as a listed peer group is not a valid approach, since microfinance behaves very differently in terms of risk and thus cannot be regarded as the same asset class.
} 
valuation, and by the allocation of corporate expenses at the divisional level. Such issues can be addressed by using net operating income (NOI) instead of earnings, since NOI tends to reflect more accurately the performance of an institution over a given time period. Further, the approach suffers from the fact, that it compares backward-looking accounting data with forward-looking market data (stock prices). Several studies ${ }^{12}$ have analyzed the relationship between accounting betas and market betas, and have generally found significant correlations. For example, one study finds significant correlations between accounting betas and market betas in the banking industry, ranging from thirty to sixty percent, depending on the market index employed [Karels and Sackley, 1993]. Such empirical evidence combined with the approach of using parameters of emerging market institutions in general as well as emerging market commercial banks as benchmarks, suggests that it is possible to derive - at least in terms of relative market risk - meaningful conclusions from this approach.

With respect to microfinance specifically, the value of the accounting beta is further potentially diluted by data constraints, discussed below. Since the general problems associated with the use of accounting betas and additional caveats regarding data constraints are of concern, we further examine changes with respect to five key financial variables:

1. Return on equity (ROE)

2. Profit margin (PM)

3. Change in total assets (TA\%)

4. Change in gross loan portfolio (GLP\%)

5. Loan portfolio at risk (PAR) ${ }^{13}$

Variables 1 and 2 are used as profitability indicators, and variables 3 and 4 indicate changes in the value of assets, while variable 5 is an indicator of the

\footnotetext{
${ }^{12}$ See, for example, Ball and Brown (1996), Beaver, Kettler and Scholes (1970), Gonedes (1973), Beaver and Manegold (1975), Kulkarni, Powers and Shanon (1991) and Karels and Sackley (1993)

${ }^{13}$ Measured in terms of portfolio at risk > 30 days / gross loans for MFIs and impaired loans / gross loans for EMCBs
} 
loan portfolio quality. Variables 1 to 5 for financial institutions (variables 1 to 3 for non-financial institutions) are assumed to capture key changes in the fundamental value of an institution, which ultimately defines its market value. If it can be shown that some of the key variables are significantly more exposed to market movements for our benchmarks than they are for MFIs, this would indicate that the latter are generally less exposed to systemic risk. Jansson and Taborga [2000] note that three additional issues are fundamental for MFIs liquidity, capital, and efficiency and productivity. They should not, however, affect the results of the analysis. ${ }^{14}$

In addition to exploring the relationship of MFI returns to the S\&P 500, Morgan Stanley Capital International (MSCl) World and $\mathrm{MSCl}$ Emerging Markets equity indexes as proxies for global market risk, we further analyze the relationship with domestic GDP, as proxy for domestic market risk. Although for international investors country risk is diversifiable, usually this is not the case for domestic emerging market investors. We chose domestic GDP instead of domestic stock indexes for several reasons: Emerging market stock indexes are often limited to a small number of locally listed firms and may not accurately reflect underlying national economic performance. In many emerging markets, betas are likely to be close to one for the large companies that dominate the local index and are wildly variable for all other companies. Moreover, since some of the emerging market institutions and/or commercial banks in the sample are likely to represent significant parts of domestic stock markets, reverse causality could be a major problem associated with choosing domestic stock indexes as an independent variable. Additionally, it was possible to gather accurate stock market information for only about half of the 85 countries in our sample, which would have led to the loss of a large number of

\footnotetext{
${ }^{14}$ Since loans represent a very large percentage of MFI assets (the average loan portfolio to total assets ratio is $78 \%$ in our sample) with very short average maturity, liquidity should not be a major concern regarding fundamental stability of MFIs as long as the portfolio quality does not deteriorate dramatically. Capital is an important measure, but since virtually all systemic changes in this category should be captured by changes in net operating income and PAR30, a lack of sufficient data in this category should not be a major concern. Finally, efficiency and productivity should not be heavily exposed to market impacts, as long as PAR30 remains within acceptable limits.
} 
observations. Finally, GDP - being backward-looking - does not have the same problem as the forward-looking indexes we used in our global analysis. We nevertheless tested the relationship with the domestic stock index for all three types of institutions and found significant correlations only for the top 325 emerging market institutions (Appendix 6).

\section{Dataset}

Our dataset comprises annual data covering the period from 1998 to $2006 .{ }^{15}$ All numbers and ratios used are calculated from US dollar conversions of localcurrency financial information at contemporaneous exchange rates. Entrants and exits are treated exactly as other institutions. No lags are assumed between the independent and dependent variables. We tested our results with 1 and 2 year lag factors, and did not find any stronger results. Due to the fact that MFIs have significantly shorter lending maturities, the dilution effect of the results due to a lag factor regarding portfolio at risk should be more significant regarding emerging market commercial banks. Given the data constraints, we cannot control for potential survivorship bias - anecdotal evidence provided by a MIX researcher suggests that survivorship bias should not be a major concern since few leading MFIs disappeared in past decade.

Data on the S\&P 500, MSCI World equities and MSCI Emerging Market equities indexes were obtained from Thomson Datastream. Data on domestic stock indexes and domestic GDP were obtained from the Economist Intelligence Unit.

All data on MFIs were obtained from the MicroBanking Bulletin (MBB) database ${ }^{16}$ of the Microfinance Information Exchange, Inc. (MIX). Participation in this database is voluntarily, but included MFIs must submit substantiating documentation, such as audited financial statements, annual reports, ratings, institutional appraisals and other materials that help external analysts

\footnotetext{
${ }^{15}$ For emerging market commercial banks, only 2000 to 2006 data was available

${ }^{16}$ The MicroBanking Bulletin (MBB) is the premier benchmarking source for the microfinance industry. Among other, it publishes financial and portfolio data, which is provided voluntarily by microfinance institutions (MFIs) and organized by peer groups.
} 
understand their operations, so that the database is somewhat self-selected. In Gonzalez [2007] the responsible MIX researcher explains that the ability to report full and consistent data is related to the availability of adequate information systems, capacity of providing all information necessary to satisfy the minimum requirements of audit firms and willingness to share detailed financial information - which is in turn driven by the potential exposure to investors and donors looking for investment opportunities among MFIs. Gonzalez concludes that the database can be viewed as a random sample of the best MFIs in the world, but definitely not a random sample of all MFIs. We argue that our data sample is the best available representation of the world's top MFIs, and therefore the potential MFI investment universe for (international) portfolio investors.

While the MIX performs extensive checks on the consistency of data reported, it does not independently verify the information. According to the Executive Director of the MIX, MBB database is the largest of its kind by far and has been termed a "remarkably clean" dataset by the World Bank when it used MBB in its own research. Apart from closely monitoring the data quality of all participating MFIs, the MIX applies certain adjustments, including accounting for inflation, loan loss provisioning and most importantly subsidies. ${ }^{17}$ In particular, participating institutions' financial statements are adjusted for the effect of subsidies by presenting them as they would appear in the absence of any subsidies. Although from an investor perspective MFI subsidies - which dilute the real market risk of institutions - can be compared to the too-big-to-fail (TBTF) support of commercial banks ${ }^{18}$, investors should care about the underlying market risk, since subsidies are neither predictable nor enforceable. Furthermore, they are increasingly being replaced by commercial funding. In 2006 , approximately $60 \%$ of MFI funding was on commercial terms, including customer deposits and commercial borrowings, an increase from just $40 \%$ in

\footnotetext{
${ }^{17}$ MicroBanking Bulletin, Issue 15 (2007) contains details on these adjustments.

${ }^{18}$ TBTF is a term used to describe that large financial institutions are likely to be bailed out by national supervisory institutions in times of severe financial distress, given that their collapse could endanger the stability of the financial system.
} 
2003. This trend holds across nearly every region and every type of MFI. Well ahead of MFIs in other regions, the median Latin American MFI was sourcing nearly $90 \%$ of its loan portfolio from commercial debt and customer deposits by the end of 2005 [MIX, 2007].

Although the MBB database currently contains 790 MFIs, we only include data from MFIs with at least three consecutive years of financial statements in order to increase the quality of the dataset and to make it more comparable to the datasets of our benchmarks. This leaves $325 \mathrm{MFIs}$ based in 66 emerging market countries.

Regarding emerging market commercial institutions in general we use data from ORBIS, a database compiled by Bureau van Dijk on 14 million private and public companies worldwide. To make this dataset comparable with the MFI dataset, we only included the top 325 (in terms of 2006 earnings) emerging market firms, based in 23 emerging market economies. Further, we excluded commercial banks to avoid redundancies with our EMCB dataset. For both EMIs and EMCBs we also excluded countries which were identified as emerging markets but did not have any microfinance sector (e.g. Cayman Islands, the OPEC countries, etc.)

Regarding emerging market commercial banks we use BankScope, a Bureau van Dijk database, covering over 27,000 banks around the world. Here as well we include the top 325 institutions (in terms of 2006 earnings), based in 49 emerging market economies.

Although we attempted to maximize the quality of the dataset, it continues to have its limitations regarding volume, consistency and precision as well as the accounting standards applied. Such constraints potentially reduce the $R^{2}$ values and lead to higher standard errors. In our dataset, the volume of available financial information is relatively low per institution ${ }^{19}$ (maximum of nine observations per institution), but arguably sufficient due to the relatively large number of institutions included (325 each of MFIs, EMIs and EMCBs). Even if the observed $\mathrm{R}^{2}$ values potentially bias downward systemic risk, it

\footnotetext{
${ }^{19}$ for MFIs even more so than for EMIs and EMCBs as can be seen in Exhibit 1
} 
should be possible to derive meaningful conclusions at least regarding the relative market risk of MFIs, if apart from the volume consistency and precision of our MFI and benchmark datasets are generally comparable.

Although data on microfinance remains less reliable than data on established emerging market commercial banking institutions (mainly due to differences in regulation and hence reporting standards), significant progress has been made in recent years in terms of enhancing quality and consistency in disclosure. The financial statements of all MFIs included in this study are monitored by the MIX and can show at least three consecutive years of financial statements (of which $75 \%$ are audited). Consequently, even if they operate under local accounting standards, most have gone through the rigor of external audits. The larger MFIs during the period under study used International Financial Reporting Standards (IFRS) - formerly International Accounting Standards (IAS). Very few used US Generally Accepted Accounting Practices (GAAP). Many of the smaller MFIs used national accounting standards that were generally in the process of being aligned with IFRS. Given the simplicity of MFI business models, there does not appear to be much variation due to differences in local accounting standards. Similar issues relating to accounting standards arise in compiling data on established emerging market commercial and financial institutions, as well as equity indexes such as MSCl World Equities, which are based on an amalgam of US GAAP and IFRS data. Overall, the similar numbers of observations used, combined with the increasingly comparable data quality, accounting practices and auditing process suggests that data on MFIs and our performance benchmarks can be used in defensible statistical comparisons.

\section{Methodology}

We use a fixed-effects regression model, which controls for differences in the levels of variables associated with individual institutions - a standard approach when dealing with panel data. As in any OLS regression model, the key assumption is that the impact of the independent variable is the same for a 
given type of institution. Other available models such as the random effects estimator may yield more precise results, but only at the expense of stronger assumptions - which in this case are certain to be excessively restrictive and contain a high risk of misspecification bias in the results.

First, we conduct an individual OLS regression for MFIs to test whether MFIs are correlated with global and domestic markets. Second, we run an OLS regression with MFIs and EMIs and an interaction term of a dummy variable for EMIs and the explanatory variable. The significance level of the interaction term coefficient provides a direct test for differences between the two types of institutions, to ascertain whether MFIs are significantly less correlated than other emerging market investments in general. We repeat the same test with EMCBs, to test whether MFIs are less correlated than emerging market commercial banks, and thus can be regarded as a separate asset class in terms of their risk profiles. The findings are shown in Exhibits 2 to 6, which present the statistical significance of the regression coefficients - t-values are in parentheses following the regression coefficient, and significant results are marked in bold ("significance" is defined at the 95\% level of confidence and "high significance" at the $99 \%$ level of confidence).

\section{Regression analysis of Microfinance with Global Capital Markets}

Most regression coefficients and $\mathrm{R}^{2}$ values obtained are low. One explanation is our use of accounting data. As noted, accounting earnings are backward-looking and tend to be smoothed relative to the underlying value of the company, as accountants spread expenses and income over multiple periods. This reduces the apparent sensitivity to market movements (regression coefficients) and market-risk $\left(R^{2}\right)$ for $\mathrm{NOI}$ and our profitability indicators, since market impacts are not directly reflected in annual accounting results. Another problem with our NOI results is the high frequency of missing observations in the database. ${ }^{20}$ Furthermore, the substandard quality of the accounting data for MFIs and to a lesser extent also for EMIs and EMCBs

\footnotetext{
${ }^{20}$ see Exhibit 1 in the appendix
} 
creates variation that cannot be explained by the model, and therefore lowers the $R^{2}$ values for all our results.

The percentage change in net operating income does not show a statistically significant correlation with the S\&P 500 index, MSCI World Equities Index and $\mathrm{MSCl}$ Emerging Markets Index for MFIs, but does exhibit significant correlations for EMIs and EMCBs with respect to all three indexes. With respect to the S\&P 500 and the MSCl World indexes, MFIs show highly significantly lower sensitivity than EMIs and EMCBs.

Regarding operating fundamentals, MFIs only exhibit significant correlation with respect to profit margin against the $\mathrm{MSCl}$ World Index. Even in this case, the coefficient is low (0.1). All $R^{2}$ values are extremely low (consistently below $0.5 \%$ ), indicating very low market risk, even though the "real" values should be somewhat higher due to the use of (substandard) accounting data.

EMIs and EMCBs consistently show statistically significant correlation against all three global market performance measures in terms of all operating fundaments analyzed. $R^{2}$ values are consistently much higher for EMIs (up to $6 \%$ ) and EMCBs (up to $11.5 \%$ ), indicating a much higher exposure to global market movements.

Highly significant differences between MFIs and EMIs / EMCBs are evident regarding asset sensitivity against all three global performance measures. A $10 \%$ drop in the S\&P 500 for example, is expected to lead to no impact on MFIs in terms of the asset measure, whereas EMIs and EMCBs are expected to lose approx. $4 \%-5 \%$ of their asset value. Furthermore, both profitability and loan portfolio quality of MFIs seems to be less sensitive to global market movements than in the case of EMCBs, as indicated by consistent highly significant differences.

\section{Regression analysis of Microfinance with the Domestic Economy}

Domestically, changes in net operating income of MFIs show no relationship with GDP movements. EMIs and EMCBs on the other hand display 
highly significant correlation. Nevertheless, we did not find significant differences for the three sets of firms regarding sensitivity of NOI.

The fundamental variables associated with MFIs show highly significant correlation for all five parameters tested. The signs of the regression coefficients are as expected, showing cyclical behavior. Profit margins seem to be the most exposed, with an $R^{2}$ value of almost $5.5 \%$, followed by portfolio at risk with an $R^{2}$ value of almost $4 \%$.

EMIs and EMCBs also exhibit highly significant correlation for all fundamental variables tested. Market risk seems to be generally higher for EMIs and EMCBs, with $\mathrm{R}^{2}$ values that are - apart from profit margin consistently higher for these types of institutions. This can either stem from a lower quality of MFI information in the dataset or from fundamental differences - discussed at the end of this section. Still, EMIs and EMCBs show significantly less sensitivity than MFIs regarding profit margin: A 5\% drop in GDP is associated with an approximately 4-5\% greater drop in profit margin for MFIs than for EMIs / EMCBs. MFIs once again display significantly lower sensitivity regarding portfolio at risk - a $5 \%$ decline in GDP is expected to increase portfolio at risk by approx. $0.75 \%$ more for EMCBs than for MFIs.

\section{Stress-testing the results}

Since current data do not permit rigorous statistical stress-testing of the results, we refer to existing case-study based research on the resilience of MFIs under conditions of severe macroeconomic distress. In an overview of the performance of MFIs during economic and financial crises in emerging markets, Gonzalez and Rosenberg [2006] suggest that MFIs significantly outperform commercial banks. Studies by Jansson [2001] on Colombia, Peru and Bolivia, MicroRate [2004] on Bolivia, Fonseca [2004] on Argentina, Ecuador and Bolivia, Duff and Phelps on Colombia [Aristizabal, 2006] and Patten, Rosengard and Johnston [2001] on Indonesia find that - although MFIs are not immune to macroeconomic shocks - they tend to be significantly less effected than commercial banks. Furthermore, MFIs seem to recover faster 
from times of economic distress than do commercial banks. The correlation with major adverse market movements seems to differ among countries and types of microfinance institutions.

\section{Why Microfinance May Be Different}

The empirical evidence presented in this study suggests that MFIs are to a significant extent detached from international capital markets, which significantly and increasingly affect the performance of emerging market institutions [Saunders and Walter, 2002]. In this section we consider possible sources of these differences in risk exposure between MFIs and EMIs / EMCBs and the extent to which MFIs will be able to sustain this advantage as the microfinance industry matures. Arguable, differences in risk exposure between MFIs and EMIs are mainly due to variation regarding ownership and governance structure as well as international exposure of clients. Regarding EMCBs it can be argued that additionally differences regarding operational and financial leverage as well as product and lending methodologies could have an impact.

\section{Ownership and Governance}

All EMIs and EMCBs included into the study are publicly traded companies, where shareholders mainly consist of domestic and international portfolio investors. The lack of a dominant long-term investor base in most emerging markets is often associated with substantial stock market volatility in these countries, with investors largely driven by technical trading strategies. International portfolio investors are highly sensitive to market signals, and emerging market crises have demonstrated their impact on local markets once

cross-border capital flows suddenly reverse direction. One consequence of such sharp reductions in local market liquidity is often a dramatic drop in the 
value of listed companies, which reduces the KMV "distance to default" of these institutions. $^{21}$

MFIs, on the other hand, are virtually all privately-held companies, with the main shareholders generally consisting of various kinds of institutions both for-profit and nonprofit investors who have a long-term strategic interest and are less driven by market forces. Jansson [2001] finds that strong ownership structures - with owners who have financial resources and sufficient equity stakes to closely monitor MFIs - are a key advantage..$^{22}$

A second implication of a sudden decrease in local-market liquidity is that refinancing becomes increasingly difficult for EMIs and especially for EMCBs with asset-liability maturity mismatches. Here again MFIs seem to have an advantage - i.e., continuous funding via international development agencies and socially responsible investors that understand the importance of this sector for the local economy [Fonseca, 2004].

If MFIs increasingly become commercial enterprises which access domestic and international financial markets, the stability advantage in terms of ownership structures is likely to deteriorate. With respect to the 1997-98 Asia financial crisis, for example, McGuire and Conroy [1998] find that microfinance appears to have suffered most where it was linked into the formal financial system and caught up in local financial crises.

\section{Client Characteristics}

MFIs target the "unbankable" - domestic customers with very low income and virtually no collateral. Most microfinance customers represent "entrepreneurs", often one of the prerequisites of obtaining microfinance credit. This restriction, combined with clients' awareness of the high productivity of early-stage capital expenditures, explains a significantly higher investment ratio

\footnotetext{
${ }^{21}$ The KMV model of default risk considers that the equity of a firm essentially represents a call option with an exercise price that is equal to the book value of the firm's debt. The model calculates the probability of default based on the distance between the firm's value and its debt. A significant decline in the value of a company is associated with an increase of the risk of bankruptcy. See http://www.moodyskmv.com/.

${ }^{22}$ See also Franks [2000].
} 
for MFI customers. Investing instead of consuming can reduce exposure to market risk.

In addition to showing more resilience and a higher capacity to adapt [Fonseca, 2004] micro-entrepreneurs may be less integrated into the formal sector of the economy. Whereas EMI / EMCB customers consist of international corporations and individuals exposed to international market movements or domestic clients well integrated into the market and possibly import-dependent, micro-entrepreneurs may mainly sell domestically-produced goods and services to low-income domestic clients who are to a certain degree detached from the formal domestic market and even more so from the international market. Moreover, the tendency for customers to move "downmarket" to cheaper, domestically produced goods during times of economic stress may have a countercyclical effect on micro-entrepreneurs who supply them. Micro-borrowers may also value their access to credit more highly than ordinary commercial bank customers, since it may represent their only opportunity to borrow, and therefore they make greater personal sacrifices to sustain it [Patten, Rosengard and Johnston, 2001]. As Robinson [2001] points out, fewer alternative sources of financing increase repayment discipline, and thus may support the resilience of MFIs to financial crises.

Although empirical and theoretical evidence generally points out that MFI client characteristics are favorable, idiosyncrasies are not necessarily permanent, and mission-drift away from the poorest - a strategy that may appear attractive in terms of increasing returns - potentially has a negative impact in terms of MFI exposure to systemic risk. Focusing on Indonesia, Malaysia, Philippines, Thailand and South Asia during the 1997-98 Asia crisis, McGuire and Conroy [1998] find that countries with the greatest concentrations of poverty were materially less affected by the regional financial shock. They also find that MFIs focusing solely on the poor appear to have withstood the crisis better than lenders not specifically targeting the poor. Finally, an InterAmerican Development Bank study on Bolivia [Rodriguez, 2002] finds that institutions serving principally or exclusively low-income women showed a 
higher degree of sustainability in times of crisis. Such evidence suggests that MFIs which continue to focus on the poor entrepreneurs and maintain a deep understanding of, and close ties to, their customers may be able to preserve their resistance to macroeconomic crises.

\section{Product Characteristics}

The average loan of a commercial bank is much larger in size, bears a lower interest rate, and has a longer maturity than the average MFI loan. The first two characteristics should not have a major impact on systemic risk - i.e., the greater granularity of MFIs portfolios decrease only their firm-specific risk. Loan maturity, on the other hand, influences the exposure to market risk. Retail banks are in general adversely affected by increases in interest rates, since their borrowing rates tend to be highly flexible (often floating), whereas their lending rates tend to be "sticky". A longer average maturity of outstanding loans increases this inflexibility and reduces their ability to adjust lending terms or to temporarily reduce lending activity in case of unfavorable movements in interest rates.

Differences in product characteristics suggest that MFI mission-drift away from services to the poor would come at the expense of a higher exposure to systemic risk as against MFIs that continue to focus on small loans with short average maturities.

\section{Lending Techniques}

Microfinance lending differs from traditional commercial banking mainly in the lack of collateral. Since loan covenants such as pledges of collateral reduce exposure to credit risk, commercial banks seem to have an advantage in terms of portfolio quality. In a theoretical paper, Bond and Rai [2006] argue, that for MFI customers the prospect of subsidized future loans is a primary source of current debt service discipline and accounts for low default rates. The expected withdrawal of subsidized future lending as a result of current defaults by fellow micro-borrowers (due for example to natural disasters or other local shocks) will 
eliminate that discipline and the resulting contagion will endanger the viability of the MFI. The authors suggest that larger MFI reserves and insurance arrangements to underwrite their continued viability will help constrain contagion.

However, there are several "soft factors", which can turn out to be more important than collateral, especially in countries with unstable or inefficient legal systems. The very short periods between installments (usually weekly or biweekly) allow MFIs to carefully monitor portfolio quality and rapidly adjust their lending practices and liquidity if necessary. Jansson [2001] explains the superior economic performance of MFIs during times of economic distress in terms of "close ties to and knowledge of borrowers and local markets, and solid screening and incentive mechanisms to identify and encourage good and strong clients." A GTZ study finds that women, who represent a large percentage of MFI clients, tend to have above-average debt service reliability. ${ }^{23}$ Borrower "circles" and mutual support practices may further cut microloan defaults. Marconi and Mosley [2005] find that organizations which provide savings, training and quasi-insurance services perform particularly well under stress conditions. In general, the "village-banking model" 24 and lending principally or exclusively to low-income women appears to be important in reducing credit losses in times of financial distress.

While MFIs have a disadvantage with respect to collateral, they may thus have offsetting advantages with respect to screening and relationship management. Whereas better enforcement of property rights and credit reporting standards will help MFIs increasingly secure loans with collateral, their strong local ties and commitment to serve the poor may support high portfolio quality even in times of financial distress.

\footnotetext{
${ }^{23}$ For cites to the relevant GTZ studies, see http://search.gtz.de/livelinkger/livelink.exe/1972878903.

${ }^{24}$ Community-run and community-focused credit and savings associations, particularly in areas untouched by the formal financial services industry. The village banking method is highly participatory. It gives beneficiaries a voice and it involves them in the development process. Members not only receive loans, they form cohesive groups who manage and collect repayments on those loans, who save diligently and decide on ways to invest those savings, and progress together, forming networks for mutual support. (Source: www.villagebanking.org)
} 


\section{Differences in Operating Leverage}

Ceteris paribus, higher operating leverage results in greater earnings variability. Although reliable data on the relevant variables is unavailable for MFIs, our dataset indicates that commercial banks may have a higher operating leverage, since they tend to be more dependent on fee-based services such as investment management, mortgage origination, transactionbanking and credit card business. ${ }^{25}$ Apart from being more volatile [DeYoung and Roland, 1999], the input mix required to supply such financial services may generate higher fixed costs than those needed to provide traditional credit products. MFIs that diversify their activities may indeed reduce firm-specific risk, but adding business lines with higher fixed-costs will tend to increase their operating leverage and exposure to systemic risk.

\section{Differences in Financial Leverage}

Financial leverage has the same effect as operating leverage, since interest rate payments are part of the fixed obligations of a company. Thus, increased financial leverage tends to raise earnings volatility. MFIs in our dataset have an average debt-equity ratio of 2.6, while that for commercial banks averages $7.5 .{ }^{26} \mathrm{~A}$ mean tax rate of $19 \%$ for both types of institutions suggests that MFIs would need an equity beta of approximately 2.3 times the equity beta of commercial banks to incur the same market risk exposure.

Debt/equity ratios for MFIs increased from an average of 1.9 in 2004 to 2.6 in $2007 .{ }^{27}$ Whereas NGOs usually find it difficult to borrow more than twice their equity, debt-to-equity ratios among regulated MFIs are comparable to those of commercial banks. ${ }^{28}$ As the industry matures and MFIs become regulated financial institutions, the differences in financial leverage between MFIs and commercial banks are likely to diminish. The positive impact on MFIs

\footnotetext{
${ }^{25}$ The ratio of total loans to total assets averaged almost $80 \%$ for MFIs, while that of emerging market commercial banks averaged approximately only 55\% during the period under study

${ }^{26}$ Data for MFIs was obtained from MicroBanking Bulletin, issue 15. For EMCBs, we used as a proxy the average ratio of U.S. commercial banks.

${ }_{27}$ Source: Microbanking Bulletin, Issues 11 and 15 (2007).

${ }^{28}$ MFIs with banking license have avg. debt/equity ratio of 6.7 (Microbanking Bulletin, issue 15)
} 
of an increase in financial leverage - in terms of moving towards an optimum capital structure - and the resulting (potentially) higher growth and profitability comes at the expense of an increase in systemic risk.

\section{Conclusions}

This paper examines systemic risk associated with microfinance. With the exception of profit margin against the MSCI World Index, MFIs in our study display no statistically significant relationship with global market movements. Regarding exposure to domestic GDP, MFIs display - apart from net operating income - highly significant correlation with all parameters analyzed, demonstrating that MFIs are not detached from their respective domestic economies.

Comparing market risk of the leading MFIs with the leading emerging market institutions (EMIs), MFIs show highly significantly less sensitivity with global capital markets in terms of income and assets. We did not find any significant differences regarding our profitability measures. $R^{2}$ values of EMIs are consistently much higher than for MFIs, indicating a higher exposure of EMls to global capital markets. With respect to domestic GDP, MFIs display significantly higher sensitivity regarding their profit margin. Still, $\mathrm{R}^{2}$ values for all other parameters are much lower for MFIs, indicating an overall lower exposure to the domestic economy.

Comparing global market risk of MFIs with emerging market commercial banks, MFIs consistently show significantly or highly significantly less sensitivity for all parameters analyzed - with the exception for net operating income against the $\mathrm{MSCl}$ Emerging Market index. As with EMIs, $\mathrm{R}^{2}$ values of EMCBs are consistently much higher than for MFIs, indicating a higher exposure of EMCBs to global capital markets. Regarding the relationship with domestic GDP, MFIs display highly significantly higher sensitivity regarding their profit margin, but significantly lower sensitivity regarding their portfolio quality. Once again, MFIs display with the exception of profit margin consistently much lower $\mathrm{R}^{2}$ values, indicating a lower overall exposure to the domestic economy. 
MFIs seem to a significant degree detached from global capital markets, as indicated by consistently very low regression coefficients and $R^{2}$ values, both in absolute terms and in relative terms to our benchmarks. On the other hand, MFIs do not seem to be nearly as detached from their domestic markets, as indicated by regression coefficients comparable to other emerging market institutions. Still, overall domestic risk exposure might be lower than for most alternative emerging market investments, as indicated by almost consistently lower $\mathrm{R}^{2}$ values. The results suggest that MFIs may have useful diversification value for international portfolio investors able to diversify away from country risk exposures. ${ }^{29}$ For emerging market domestic investors, who may have this ability to a much more limited extent, domestic microfinance investments do not seem to provide significant portfolio diversification advantages.

We argue that the difference in market risk between microfinance and other emerging market institutions is based on a generally non-public ownership structure which reduces dependence on capital markets, lower international exposure of microfinance clients as well as lower operational and financial leverage. It follows that as the microfinance industry matures market risk associated with MFIs will increase, although due to client characteristics most likely to a lower level than for most other emerging market investments.

This study complements other research regarding the performance of MFIs, and represents one of the first attempts to estimate the systemic risk associated with microfinance. As such, it is constrained by problems of data quality and applicable methodology. The absence of marked-to-market valuation for MFIs renders data availability the most important constraint to empirical research in this area. Still, we would argue that the levels of significance obtained suggest that the results are of interest. With MFIs increasingly tapping the capital markets and adhering to well-defined reporting standards, future studies may be able to confirm our results at a higher level of confidence.

\footnotetext{
${ }^{29}$ The risk/return story for international portfolio investors is perhaps further enhanced by the fact that our data are corrected for subsidies so that securitized microfinance would actually incorporate a subsidy element and enhance its investor attractiveness.
} 


\section{REFERENCES}

Acción (2006), "Who Will Buy Our Paper? Microfinance Cracking the Capital Markets", Insight, 18.

Ahlin, Christian and Jocelyn Lin (2006), "Luck or Skill? MFI Performance in Macroeconomic Context," BREAD Working Paper No. 132, October

Aristizabal, Gustavo (2006), "The Nuts and Bolts of Rating Microfinance Institutions: Case from Colombia", Duff \& Phelps de Colombia.

Bond, Philip and Ashok S. Rai (2006), "Borrower Runs in Microfinance", Working Paper, Wharton Finance Department, May.

Callaghan, Ian, Henry Gonzalez, Diane Maurice and Christian Novak (2007), "Microfinance - On the Road to Capital Markets", Journal of Applied Corporate Finance 19 (1), pp. 115-124

Consultative Group to Assist the Poor (2002), Donor Brief, 6.

Consultative Group to Assist the Poor (2004), Annual Report.

Credit Suisse (2005), "Microfinance”, Global Investor Focus, Spring.

DeYoung, Robert and Karin P. Roland (1999), "Product Mix and Earnings Volatility at Commercial Banks: Evidence from a Degree of Leverage Model", Working Paper Series Federal Reserve Bank of Chicago.

Ehrbeck, Tilman (2006), "Optimizing Capital Supply in Support of Microfinance Industry Growth," McKinsey \& Co. presentation at Microfinance Investor Roundtable, Washington, D.C., October 24-25.

Easton, Tom (2005), "The Hidden Wealth of the Poor", The Economist, November 5.

Fonseca (2004), "Facing the Music: How to Survive in the Midst of Crisis", Microenterprise Americas.

Franks, Jeffrey (2000), "Macroeconomic Stabilization and the Microentrepreneur", The Journal of Microfinance, 2 (1).

Gonzalez, Adrian, (2007) "Resilience of Microfinance Institutions to National Macroeconomic Events: An Econometric Analysis of MFI Asset Quality. Working paper. Available at SSRN: http://ssrn.com/abstract=1004568 
Gonzalez Adrian and Richard Rosenberg, (2006), "The State of Microcredit Outreach, Profitability, and Poverty," Access to Finance: Building Inclusive Financial Systems Conference, World Bank, May 30

Jansson, Tor (2001), "Microfinance: From Village to Wall Street", InterAmerican Development Bank.

Jansson, Tor and Miguel Taborga (2000), "The Latin American Microfinance Insdustry: How does it Measure up?" Inter-American Development Bank.

Karels, G.V. and W.H. Sackley, "The Relationship Between Market and Accounting Betas for Commercial Banks," Review of Financial Economics 2, 1993, pp. 59-72.

Krauss, Nicolas and Ingo Walter (2006), "Can Microfinance Reduce Portfolio Volatility", Available at SSRN: http://ssrn.com/abstract=943786

Littlefield, Elizabeth and Holtman, Martin (2005), in "Microfinanciers Overtake their Commercial Peers", The Banker, July 4.

Marconi, Reynaldo and Paul Mosley (2005), "Bolivia during the Global Crisis 1998-2004: Towards a macroeconomics of microfinance", Sheffield Economic Research Paper Series.

McGuire, Paul and John Conroy (1998), "Effects on Microfinance of the 19971998 Asian Financial Crisis," Foundation for Development Cooperation, Brisbane, Australia, November.

Microfinance Information eXchange (MIX) (2007), The MicroBanking Bulletin, Issue No. 14

Microfinance Information eXchange (MIX) (2007), The MicroBanking Bulletin, Issue No. 15

Patten, Richard, Jay Rosengard and Don Johnston (2001), "Microfinance Success Amidst Macroeconomic Failure: The Experience of Bank Rakyat Indonesia During the East Asian Crisis", World Development, 29 (6), pp. 10571069.

Robinson, Marguerite (2001), "The Microfinance Revolution. Sustainable Finance for the Poor", The World Bank.

Saunders, Anthony and Ingo Walter (2002), "Are Emerging-Market Equities A Separate Asset Class?", Journal of Portfolio Management, Spring. 
Swanson, Brad (2007), "The Role of Capital Markets in Microfinance," paper presented at a symposium on Credit Markets for the Poor, Columbia University Business School, April 20. Paper available at http://www2.gsb.columbia.edu/socialenterprise/academics/research/symposium 07

von Stauffenberg, Damian (2007) "Survey of Microfinance Investment Vehicles," paper presented at a symposium on Credit Markets for the Poor, Columbia University Business School, April 20. Paper available at http://www2.gsb.columbia.edu/socialenterprise/academics/research/papers/Mic roRate_MIV_Survey.pdf 
Exhibit 1

Description of Dataset

\begin{tabular}{|c|c|c|c|c|c|c|c|c|c|c|}
\hline \multirow[b]{2}{*}{$\begin{array}{l}\text { Dependent } \\
\text { Variables }\end{array}$} & \multicolumn{10}{|c|}{ Top 325 MFIs } \\
\hline & \# Obs. & \# Inst. & $\begin{array}{l}\text { avg. \# } \\
\text { Obs. }\end{array}$ & Median & Mean & Min. & 5\% Perc. & 95\% Perc. & Max & Std. Dev. \\
\hline $\begin{array}{l}\text { Net operating } \\
\text { Income \% change }\end{array}$ & 786 & 312 & 2.5 & $28.5 \%$ & $34.9 \%$ & $-491 \%$ & $-209 \%$ & $288 \%$ & $491 \%$ & $145 \%$ \\
\hline Return on Equity & 1475 & 325 & 4.5 & $5.8 \%$ & $5.1 \%$ & $-170 \%$ & $-33 \%$ & $38 \%$ & $190 \%$ & $27 \%$ \\
\hline Profit Margin & 1482 & 325 & 4.6 & $8.2 \%$ & $0.6 \%$ & $-198 \%$ & $-71 \%$ & $37 \%$ & $62 \%$ & $33 \%$ \\
\hline $\begin{array}{l}\text { Total Assets \% } \\
\text { change }\end{array}$ & 1161 & 325 & 3.6 & $32.7 \%$ & $39.5 \%$ & $-69 \%$ & $-5 \%$ & $101 \%$ & $199 \%$ & $35 \%$ \\
\hline $\begin{array}{l}\text { Loan Portfolio \% } \\
\text { change }\end{array}$ & 1169 & 325 & 3.6 & $36.9 \%$ & $45.4 \%$ & $-84 \%$ & $-9 \%$ & $133 \%$ & $284 \%$ & $44 \%$ \\
\hline Portfolio at Risk \% & 1406 & 321 & 4.4 & $2.5 \%$ & $4.3 \%$ & $0.1 \%$ & $0.2 \%$ & $14.5 \%$ & $41.8 \%$ & $5 \%$ \\
\hline
\end{tabular}

All numbers and ratios used are calculated from U.S. dollar conversion of local currency financial information

\begin{tabular}{|c|c|c|c|c|c|c|c|c|c|c|}
\hline \multirow[b]{2}{*}{$\begin{array}{l}\text { Dependent } \\
\text { Variables }\end{array}$} & \multicolumn{10}{|c|}{ Top 325 Emerging Market Institutions } \\
\hline & \# Obs. & \# Inst. & $\begin{array}{l}\text { avg. \# } \\
\text { Obs. }\end{array}$ & Median & Mean & Min. & 5\% Perc. & 95\% Perc. & Max & Std. Dev. \\
\hline $\begin{array}{l}\text { Net operating } \\
\text { Income } \% \text { change }\end{array}$ & 1908 & 314 & 6.1 & $17.4 \%$ & $33.2 \%$ & $-453 \%$ & $-64 \%$ & $199 \%$ & $483 \%$ & $88 \%$ \\
\hline Return on Equity & 2183 & 314 & 7.0 & $15.8 \%$ & $18.6 \%$ & $-191 \%$ & $2 \%$ & $49 \%$ & $155 \%$ & $17 \%$ \\
\hline Profit Margin & 2314 & 325 & 7.1 & $12.7 \%$ & $14.9 \%$ & $-94 \%$ & $-8 \%$ & $47 \%$ & $98 \%$ & $18 \%$ \\
\hline $\begin{array}{l}\begin{array}{l}\text { Total Assets \% } \\
\text { change }\end{array} \\
\end{array}$ & 1968 & 314 & 6.3 & $9.1 \%$ & $12.1 \%$ & $-98 \%$ & $-25 \%$ & $58 \%$ & $187 \%$ & $28 \%$ \\
\hline $\begin{array}{l}\text { Loan Portfolio \% } \\
\text { change }\end{array}$ & $\mathrm{N} / \mathrm{A}$ & N/A & $N / A$ & $N / A$ & $N / A$ & $N / A$ & $N / A$ & N/A & $N / A$ & $N / A$ \\
\hline Portfolio at Risk \% & $N / A$ & $\mathrm{~N} / \mathrm{A}$ & $\mathrm{N} / \mathrm{A}$ & N/A & $N / A$ & $\mathrm{~N} / \mathrm{A}$ & $\mathrm{N} / \mathrm{A}$ & $N / A$ & $N / A$ & $\mathrm{~N} / \mathrm{A}$ \\
\hline
\end{tabular}

All numbers and ratios used are calculated from U.S. dollar conversion of local currency financial information

\begin{tabular}{|c|c|c|c|c|c|c|c|c|c|c|}
\hline \multirow[b]{2}{*}{$\begin{array}{l}\text { Dependent } \\
\text { Variables }\end{array}$} & \multicolumn{10}{|c|}{ Top 325 Emerging Market Commercial Banks } \\
\hline & \# Obs. & \# Inst. & $\begin{array}{l}\text { avg. \# } \\
\text { Obs. }\end{array}$ & Median & Mean & Min. & 5\% Perc. & 95\% Perc. & Max & Std. Dev. \\
\hline $\begin{array}{l}\text { Net operating } \\
\text { Income \% change }\end{array}$ & 1591 & 325 & 4.9 & $21.9 \%$ & $31.6 \%$ & $-375 \%$ & $-29 \%$ & $129 \%$ & $482 \%$ & $61 \%$ \\
\hline Return on Equity & 1920 & 325 & 5.9 & $16.3 \%$ & $17.0 \%$ & $-191 \%$ & $-1 \%$ & $44 \%$ & $162 \%$ & $20 \%$ \\
\hline Profit Margin & 1920 & 325 & 5.9 & $13.2 \%$ & $13.5 \%$ & $-131 \%$ & $-1 \%$ & $34 \%$ & $90 \%$ & $16 \%$ \\
\hline $\begin{array}{l}\text { Total Assets \% } \\
\text { change }\end{array}$ & 1594 & 325 & 4.9 & $19.8 \%$ & $25.2 \%$ & $-98 \%$ & $-16 \%$ & $85 \%$ & $192 \%$ & $33 \%$ \\
\hline $\begin{array}{l}\text { Loan Portfolio \% } \\
\text { change }\end{array}$ & 1589 & 325 & 4.9 & $26.0 \%$ & $30.8 \%$ & $-100 \%$ & $-19 \%$ & $100 \%$ & $283 \%$ & $40 \%$ \\
\hline Portfolio at Risk \% & 1483 & 281 & 5.3 & $5.4 \%$ & $8.2 \%$ & $0.0 \%$ & $0.5 \%$ & $25.2 \%$ & $49.5 \%$ & $8 \%$ \\
\hline
\end{tabular}

All numbers and ratios used are calculated from U.S. dollar conversion of local currency financial information 
Exhibit 2 - Regressions with S\&P 500 Index

\begin{tabular}{|c|c|c|c|}
\hline & Top 325 MFIs & Top 325 EMIs & MFIs vs. EMIs \\
\hline $\begin{array}{l}\text { NOI \% change } \\
\text { (Accounting beta) }\end{array}$ & $\begin{array}{l}\text { Coefficient: }-.72(-1.33) \\
\text { r-sq: } 0.0034\end{array}$ & $\begin{array}{c}\text { Coefficient: } .58(3.62)^{\star * *} \\
\text { r-sq: } 0.0080\end{array}$ & $\begin{array}{c}\text { Coefficient: } 1.30(3.02)^{\star *} \\
\text { r-sq: } 0.0058\end{array}$ \\
\hline ROE & $\begin{array}{l}\text { Coefficient: } .02(0.58) \\
\text { r-sq: } 0.0003\end{array}$ & $\begin{array}{c}\text { Coefficient: .06 }(3.54)^{\star * *} \\
\text { r-sq: } 0.0067\end{array}$ & $\begin{array}{l}\text { Coefficient: .04 (1.17) } \\
\text { r-sq: } 0.0035\end{array}$ \\
\hline Profit Margin & $\begin{array}{l}\text { Coefficient: } .05(1.06) \\
\text { r-sq: } 0.0010\end{array}$ & $\begin{array}{c}\text { Coefficient: } .12(6.84)^{\star * *} \\
\text { r-sq: } 0.0230\end{array}$ & $\begin{array}{l}\text { Coefficient: } .07(1.74) \\
\text { r-sq: } 0.0099\end{array}$ \\
\hline Total Assets \% change & $\begin{array}{l}\text { Coefficient: } .00(0.02) \\
\text { r-sq: } 0.0000\end{array}$ & $\begin{array}{c}\text { Coefficient:.37 (10.39)*** } \\
\text { r-sq: } 0.0613\end{array}$ & $\begin{array}{c}\text { Coefficient:.37 (5.10) } \\
\text { r-sq: } 0.0376\end{array}$ \\
\hline $\begin{array}{l}\text { Gross Loan Portfolio \% } \\
\text { change }\end{array}$ & $\begin{array}{l}\text { Coefficient: } .08(0.89) \\
\text { r-sq: } 0.0009\end{array}$ & N/A & N/A \\
\hline PAR 30 & $\begin{array}{l}\text { Coefficient: } .01(1.57) \\
\text { r-sq: } 0.0023\end{array}$ & N/A & N/A \\
\hline
\end{tabular}

\begin{tabular}{|c|c|}
\hline Top 325 EMCBs & MFIs vs. EMCBs \\
\hline $\begin{array}{l}\text { Coefficient: } .28(2.48)^{*} \\
\text { r-sq: } 0.0048\end{array}$ & $\begin{array}{c}\text { Coefficient: } 1.00(2.59)^{* *} \\
\text { r-sq: } 0.0028\end{array}$ \\
\hline $\begin{array}{c}\text { Coefficient: } .15(6.09)^{* * *} \\
\text { r-sq: } 0.0227\end{array}$ & $\begin{array}{c}\text { Coefficient: } .13(3.02)^{\star *} \\
\text { r-sq: } 0.0129\end{array}$ \\
\hline $\begin{array}{l}\text { Coefficient: } .19(10.13)^{\star \star *} \\
\text { r-sq: } 0.0605\end{array}$ & $\begin{array}{c}\text { Coefficient: } .14(3.32)^{\star * *} \\
\text { r-sq: } 0.0209\end{array}$ \\
\hline $\begin{array}{c}\text { Coefficient: } .47(10.76)^{\star \star \star} \\
\text { r-sq: } 0.0837\end{array}$ & $\begin{array}{c}\text { Coefficient: . } 46(5.85)^{* * *} \\
\text { r-sq: } 0.0496\end{array}$ \\
\hline $\begin{array}{c}\text { Coefficient: } .48(8.76)^{\star \star \star} \\
\text { r-sq: } 0.0573\end{array}$ & $\begin{array}{c}\text { Coefficient: } .41(4.07)^{\star \star \star} \\
\text { r-sq: } 0.0340\end{array}$ \\
\hline $\begin{array}{c}\text { Coefficient: }-.09(-10.43)^{\star \star \star} \\
\text { r-sq: } 0.0830\end{array}$ & $\begin{array}{c}\text { Coefficient: }-.10(-8.49)^{* * *} \\
\text { r-sq: } 0.0592\end{array}$ \\
\hline
\end{tabular}

Exhibit 3 - Regressions with MSCI World Equity Index

\begin{tabular}{|c|c|c|c|}
\hline Dependent Variable & Top 325 MFls & Top 325 EMIs & MFIs vs. EMIs \\
\hline $\begin{array}{l}\text { NOI \% change } \\
\text { (Accounting beta) }\end{array}$ & $\begin{array}{l}\text { Coefficient: }-.82(-1.53) \\
\text { r-sq: } 0.0045\end{array}$ & $\begin{array}{c}\text { Coefficient: } .51(3.43)^{\star * *} \\
\text { r-sq: } 0.0072\end{array}$ & $\begin{array}{c}\text { Coefficient: } 1.33(3.16)^{\star *} \\
\text { r-sq: } 0.0059\end{array}$ \\
\hline ROE & $\begin{array}{l}\text { Coefficient: .04 (1.06) } \\
\text { r-sq: } 0.0010\end{array}$ & $\begin{array}{c}\text { Coefficient: } .09(5.17)^{\star \star \star} \\
\text { r-sq: } 0.0141\end{array}$ & $\begin{array}{l}\text { Coefficient: } .05(1.42) \\
\text { r-sq: } 0.0076\end{array}$ \\
\hline Profit Margin & $\begin{array}{l}\text { Coefficient: } .10(2.18)^{*} \\
\text { r-sq: } 0.0041\end{array}$ & $\begin{array}{c}\text { Coefficient: } .14(8.46)^{\star * *} \\
\text { r-sq: } 0.0348\end{array}$ & $\begin{array}{l}\text { Coefficient: } .04(1.08) \\
\text { r-sq: } 0.0166\end{array}$ \\
\hline Total Assets $\%$ change & $\begin{array}{c}\text { Coefficient: }-.05(-0.76) \\
\text { r-sq: } 0.0007\end{array}$ & $\begin{array}{c}\text { Coefficient: } .34(10.31)^{* * *} \\
\text { r-sq: } 0.0605\end{array}$ & $\begin{array}{c}\text { Coefficient: } .40(5.57)^{\star \star \star} \\
\text { r-sq: } 0.0373\end{array}$ \\
\hline $\begin{array}{l}\text { Gross Loan Portfolio \% } \\
\text { change }\end{array}$ & $\begin{array}{l}\text { Coefficient: .01 (0.07) } \\
\text { r-sq: } 0.0000\end{array}$ & N/A & N/A \\
\hline PAR 30 & $\begin{array}{l}\text { Coefficient: } .01(0.87) \\
\text { r-sq: } 0.0007\end{array}$ & $N / A$ & $N / A$ \\
\hline
\end{tabular}

\begin{tabular}{|c|c|}
\hline Top 325 EMCBs & MFIs vs. EMCBs \\
\hline $\begin{array}{l}\text { Coefficient: .28 }(2.53)^{*} \\
\text { r-sq: } 0.0050\end{array}$ & $\begin{array}{c}\text { Coefficient: } 1.10(2.89)^{\star *} \\
\text { r-sq: } 0.0022\end{array}$ \\
\hline $\begin{array}{c}\text { Coefficient: } .17(7.28)^{\star \star *} \\
\text { r-sq: } 0.0322\end{array}$ & $\begin{array}{l}\text { Coefficient: } .13(3.14)^{* \star} \\
\text { r-sq: } 0.0186\end{array}$ \\
\hline $\begin{array}{c}\text { Coefficient: .21 (11.97) } \\
\text { r-sq: } 0.0825\end{array}$ & $\begin{array}{c}\text { Coefficient: .12 (2.71)** } \\
\text { r-sq: } 0.0303\end{array}$ \\
\hline $\begin{array}{c}\text { Coefficient: } .44(10.60)^{* \star *} \\
\text { r-sq: } 0.0814\end{array}$ & $\begin{array}{c}\text { Coefficient: } .50(6.35)^{\star \star *} \\
\text { r-sq: } 0.0485\end{array}$ \\
\hline $\begin{array}{c}\text { Coefficient: } .49(9.34)^{* * *} \\
\text { r-sq: } 0.0646\end{array}$ & $\begin{array}{c}\text { Coefficient: } .49(4.99)^{\star \star \star} \\
\text { r-sq: } 0.0379\end{array}$ \\
\hline $\begin{array}{c}\text { Coefficient: }-.10(-12.48)^{\star \star \star} \\
\text { r-sq: } 0.1148\end{array}$ & $\begin{array}{c}\text { Coefficient: }-.11(-9.21)^{\star \star *} \\
\text { r-sq: } 0.0812\end{array}$ \\
\hline
\end{tabular}


Exhibit 4 - Regressions with MSCI Emerging Markets Index

\begin{tabular}{|c|c|c|c|c|c|}
\hline Dependent Variable & Top 325 MFIs & Top 325 EMIs & MFIs vs. EMIs & Top 325 EMCBs & MFIs vs. EMCBs \\
\hline $\begin{array}{l}\text { NOI \% change } \\
\text { (Accounting beta) }\end{array}$ & $\begin{array}{c}\text { Coefficient: }-.27(-0.68) \\
\text { r-sq: } 0.0009\end{array}$ & $\begin{array}{c}\text { Coefficient: } .19(1.96)^{*} \\
\text { r-sq: } 0.0024\end{array}$ & $\begin{array}{l}\text { Coefficient: .46 (1.50) } \\
\text { r-sq: } 0.0017\end{array}$ & $\begin{array}{c}\text { Coefficient: } .31(2.97)^{\star *} \\
\text { r-sq: } 0.0069\end{array}$ & $\begin{array}{l}\text { Coefficient: } .59(1.94) \\
\text { r-sq: } 0.0025\end{array}$ \\
\hline ROE & $\begin{array}{l}\text { Coefficient: } .03(1.46) \\
\text { r-sq: } 0.0018\end{array}$ & $\begin{array}{c}\text { Coefficient: } .04(3.85)^{\star \star \star} \\
\text { r-sq: } 0.0079\end{array}$ & $\begin{array}{l}\text { Coefficient: } .01(0.34) \\
\text { r-sq: } 0.0049\end{array}$ & $\begin{array}{c}\text { Coefficient: } .10(5.60)^{\star * *} \\
\text { r-sq: } 0.0193\end{array}$ & $\begin{array}{l}\text { Coefficient: } .07(2.37)^{*} \\
\text { r-sq: } 0.0117\end{array}$ \\
\hline Profit Margin & $\begin{array}{l}\text { Coefficient: } .04(1.51) \\
\text { r-sq: } 0.0020\end{array}$ & $\begin{array}{c}\text { Coefficient: } .05(4.43)^{\star \star *} \\
\text { r-sq: } 0.0098\end{array}$ & $\begin{array}{l}\text { Coefficient: } .00(0.09) \\
\text { r-sq: } 0.0051\end{array}$ & $\begin{array}{c}\text { Coefficient: } .14(9.78)^{\star \star *} \\
\text { r-sq: } 0.0566\end{array}$ & $\begin{array}{l}\text { Coefficient: } .09(3.20)^{* *} \\
\text { r-sq: } 0.0203\end{array}$ \\
\hline Total Assets \% change & $\begin{array}{c}\text { Coefficient: - }-.06(-1.32) \\
\text { r-sq: } 0.0021\end{array}$ & $\begin{array}{c}\text { Coefficient: } .12(5.47)^{\star \star *} \\
\text { r-sq: } 0.0178\end{array}$ & $\begin{array}{c}\text { Coefficient: .18 }(3.75)^{\star \star *} \\
\text { r-sq: } 0.0117\end{array}$ & $\begin{array}{c}\text { Coefficient: } .37(9.03)^{\star \star *} \\
\text { r-sq: } 0.0605\end{array}$ & $\begin{array}{c}\text { Coefficient: } .43(7.09)^{\star \star *} \\
\text { r-sq: } 0.0367\end{array}$ \\
\hline $\begin{array}{l}\text { Gross Loan Portfolio \% } \\
\text { change }\end{array}$ & $\begin{array}{l}\text { Coefficient: - }-.05(-0.84) \\
\text { r-sq: } 0.0008\end{array}$ & $N / A$ & $N / A$ & $\begin{array}{c}\text { Coefficient: } .40(7.69)^{\star * *} \\
\text { r-sq: } 0.0447\end{array}$ & $\begin{array}{c}\text { Coefficient: } .45(5.84)^{* * *} \\
\text { r-sq: } 0.0266\end{array}$ \\
\hline PAR 30 & $\begin{array}{l}\text { Coefficient: } .00(0.22) \\
\text { r-sq: } 0.0000\end{array}$ & N/A & N/A & $\begin{array}{c}\text { Coefficient: }-.07(-10.60)^{\star * *} \\
\text { r-sq: } 0.0856\end{array}$ & $\begin{array}{c}\text { Coefficient: }-.07(-8.33)^{\star * *} \\
\text { r-sq: } 0.0604\end{array}$ \\
\hline
\end{tabular}


Exhibit 5 - Regressions with Domestic GDP

\begin{tabular}{|c|c|c|c|}
\hline Dependent Variable & Top 325 MFIs & Top 325 EMIs & MFIs vs. EMIs \\
\hline $\begin{array}{l}\text { NOI \% change } \\
\text { (Accounting beta) }\end{array}$ & $\begin{array}{c}\text { Coefficient: }-1.13(-0.25) \\
\text { r-sq: } 0.0002\end{array}$ & $\begin{array}{c}\text { Coefficient: } 3.78(3.30)^{* \star *} \\
\text { r-sq: } 0.0068\end{array}$ & $\begin{array}{l}\text { Coefficient: } 4.91(1.44) \\
\quad \text { r-sq: } 0.0001\end{array}$ \\
\hline ROE & $\begin{array}{c}\text { Coefficient: } .98(4.42)^{\star \star *} \\
\text { r-sq: } 0.0191\end{array}$ & $\begin{array}{l}\text { Coefficient: } 1.16(9.25)^{\star \star *} \\
\text { r-sq: } 0.0451\end{array}$ & $\begin{array}{l}\text { Coefficient: .18 }(0.77) \\
\text { r-sq: } 0.0332\end{array}$ \\
\hline Profit Margin & $\begin{array}{c}\text { Coefficient: } 2.07(7.65)^{\star \star \star} \\
\text { r-sq: } 0.0548\end{array}$ & $\begin{array}{c}\text { Coefficient: } 1.27(10.91)^{\star * \star} \\
\text { r-sq: } 0.0580\end{array}$ & $\begin{array}{c}\text { Coefficient: }-.81(-3.16)^{* *} \\
\text { r-sq: } 0.0562\end{array}$ \\
\hline Total Assets $\%$ change & $\begin{array}{c}\text { Coefficient: } 1.34(2.82)^{\star \star} \\
\text { r-sq: } 0.0110\end{array}$ & $\begin{array}{c}\text { Coefficient: } 1.91(7.33)^{\star \star *} \\
\text { r-sq: } 0.0323\end{array}$ & $\begin{array}{l}\text { Coefficient: } 0.57 \text { (1.08) } \\
\text { r-sq: } 0.0252\end{array}$ \\
\hline $\begin{array}{l}\text { Gross Loan Portfolio \% } \\
\text { change }\end{array}$ & $\begin{array}{c}\text { Coefficient: } 1.94(3.25)^{\star \star} \\
\text { r-sq: } 0.0146\end{array}$ & N/A & N/A \\
\hline PAR 30 & $\begin{array}{c}\text { Coefficient: }-.27(-6.16)^{* * *} \\
\text { r-sq: } 0.0388\end{array}$ & $\mathrm{~N} / \mathrm{A}$ & $N / A$ \\
\hline
\end{tabular}

\begin{tabular}{|c|c|}
\hline Top 325 EMCBs & MFIs vs. EMCBs \\
\hline $\begin{array}{c}\text { Coefficient: } 2.87(4.13)^{\star \star *} \\
\text { r-sq: } 0.0144\end{array}$ & $\begin{array}{l}\text { Coefficient: } 3.99(1.36) \\
\text { r-sq: } 0.0021\end{array}$ \\
\hline $\begin{array}{c}\text { Coefficient: } 1.21(7.93)^{\star * *} \\
\text { r-sq: } 0.0407\end{array}$ & $\begin{array}{l}\text { Coefficient: } .23(0.87) \\
\text { r-sq: } 0.0320\end{array}$ \\
\hline $\begin{array}{c}\text { Coefficient: } 1.00(8.65)^{\star \star *} \\
\text { r-sq: } 0.0480\end{array}$ & $\begin{array}{c}\text { Coefficient: }-1.07(-4.08)^{\star * *} \\
\text { r-sq: } 0.0523\end{array}$ \\
\hline $\begin{array}{c}\text { Coefficient: } 1.62(5.94)^{\star * *} \\
\text { r-sq: } 0.0294\end{array}$ & $\begin{array}{l}\text { Coefficient: } 0.28(0.50) \\
\text { r-sq: } 0.0228\end{array}$ \\
\hline $\begin{array}{c}\text { Coefficient: } 3.14(9.67)^{\star * *} \\
\text { r-sq: } 0.0747\end{array}$ & $\begin{array}{l}\text { Coefficient: } 1.2(1.78) \\
\text { r-sq: } 0.0522\end{array}$ \\
\hline $\begin{array}{c}\text { Coefficient: }-.42(-9.21)^{\star \star *} \\
\text { r-sq: } 0.0707\end{array}$ & $\begin{array}{c}\text { Coefficient: }-.15(-2.23)^{*} \\
\text { r-sq: } 0.0616\end{array}$ \\
\hline
\end{tabular}

Exhibit 6 - Regressions with Domestic Stock Index

\begin{tabular}{|l|c|}
\hline Dependent Variable & Top 325 MFIs \\
\hline $\begin{array}{l}\text { NOI \% change } \\
\text { (Accounting beta) }\end{array}$ & $\begin{array}{c}\text { Coefficient: }-.04(-0.27) \\
\text { r-sq: } 0.0004\end{array}$ \\
\hline ROE & $\begin{array}{c}\text { Coefficient: } 01(0.67) \\
\text { r-sq: } 0.0010\end{array}$ \\
\hline Profit Margin & $\begin{array}{c}\text { Coefficient: } .02(1.73) \\
\text { r-sq: } 0.0065\end{array}$ \\
\hline Total Assets \% change & $\begin{array}{c}\text { Coefficient: } .03(1.43) \\
\text { r-sq: } 0.0065\end{array}$ \\
\hline $\begin{array}{l}\text { Gross Loan Portfolio \% } \\
\text { change }\end{array}$ & $\begin{array}{r}\text { Coefficient: } .02(0.63) \\
\text { r-sq: } 0.0012\end{array}$ \\
\hline PAR 30 & $\begin{array}{r}\text { Coefficient: }-.00(-0.05) \\
\text { r-sq: } 0.0000\end{array}$ \\
\hline
\end{tabular}

\begin{tabular}{|c|c|}
\hline Top 325 EMIs & MFIs vs. EMIs \\
\hline $\begin{array}{c}\text { Coefficient: } \mathbf{1 2}(\mathbf{2 . 2 9})^{*} \\
\text { r-sq: } \mathbf{0 . 0 0 3 3}\end{array}$ & $\begin{array}{c}\text { Coefficient: } .16(1.54) \\
\text { r-sq: } 0.0025\end{array}$ \\
\hline $\begin{array}{c}\text { Coefficient: } \mathbf{0 2}(\mathbf{2 . 6 2})^{\star *} \\
\text { r-sq: } \mathbf{0 . 0 0 3 7}\end{array}$ & $\begin{array}{c}\text { Coefficient: } .01(1.01) \\
\text { r-sq: } 0.0029\end{array}$ \\
\hline $\begin{array}{c}\text { Coefficient: } .02(2.58)^{* *} \\
\text { r-sq: } \mathbf{0 . 0 0 3 4}\end{array}$ & $\begin{array}{c}\text { Coefficient: }-.00(-0.21) \\
\text { r-sq: } 0.0045\end{array}$ \\
\hline $\begin{array}{c}\text { Coefficient: } \mathbf{0 0 3}(\mathbf{2 . 3 2})^{*} \\
\text { r-sq: } \mathbf{0 . 0 0 3 3}\end{array}$ & $\begin{array}{c}\text { Coefficient: } .00(0.14) \\
\text { r-sq: } 0.0040\end{array}$ \\
\hline N/A & N/A \\
\hline N/A & N/A \\
\hline
\end{tabular}

\begin{tabular}{|c|c|}
\hline Top 325 EMCBs & MFIs vs. EMCBs \\
\hline $\begin{array}{c}\text { Coefficient: } .00(0.13) \\
\text { r-sq: } 0.0000\end{array}$ & $\begin{array}{c}\text { Coefficient: } .04(0.52) \\
\text { r-sq: } 0.0002\end{array}$ \\
\hline $\begin{array}{c}\text { Coefficient: }-.00(-0.22) \\
\text { r-sq: } 0.0000\end{array}$ & $\begin{array}{c}\text { Coefficient: }-.01(-0.74) \\
\text { r-sq: } 0.0003\end{array}$ \\
\hline $\begin{array}{c}\text { Coefficient: } .01(1.70) \\
\text { r-sq: } 0.0022\end{array}$ & $\begin{array}{c}\text { Coefficient: }-.01(-1.39) \\
\text { r-sq: } 0.0041\end{array}$ \\
\hline $\begin{array}{c}\text { Coefficient: } .00(0.04) \\
\text { r-sq: } 0.0002\end{array}$ & $\begin{array}{c}\text { Coefficient: }-.03(-1.35) \\
\text { r-sq: } 0.0016\end{array}$ \\
\hline $\begin{array}{c}\text { Coefficient: } .00(0.16) \\
\text { r-sq: } 0.0000\end{array}$ & $\begin{array}{c}\text { Coefficient: }-.01(-.58) \\
\text { r-sq: } 0.0004\end{array}$ \\
\hline $\begin{array}{c}\text { Coefficient: } .00(0.43) \\
\text { r-sq: } 0.0002\end{array}$ & $\begin{array}{c}\text { Coefficient: } .00(0.25) \\
\text { r-sq: } 0.0001\end{array}$ \\
\hline
\end{tabular}


Exhibit 7

Summary of Results - Statistically Significant Regression Coefficients

\begin{tabular}{|l|c|c|c|c|}
\hline \multicolumn{3}{|c|}{ Top 325 MFIs } & \\
\hline Paramter tested & S\&P 500 & MSCI World Index & MSCI EM Index & Domestic GDP \\
\hline NOI & & & & \\
\hline ROE & & & & $\checkmark$ \\
\hline Profit Margin & $\checkmark$ & & $\checkmark$ \\
\hline Total Assets \% change & & & & $\checkmark$ \\
\hline Loan Portfolio \% change & & & & $\checkmark$ \\
\hline PAR 30 & & & & $\checkmark$ \\
\hline
\end{tabular}

\begin{tabular}{|l|c|c|c|c|}
\hline \multicolumn{5}{|c|}{ Top 325 Emerging Market Instiutions } \\
\hline Paramter tested & S\&P 500 & MSCI World Index & MSCI EM Index & Domestic GDP \\
\hline NOI & $\checkmark$ & $\checkmark$ & $\checkmark$ & $\checkmark$ \\
\hline ROE & $\checkmark$ & $\checkmark$ & $\checkmark$ & $\checkmark$ \\
\hline Profit Margin & $\checkmark$ & $\checkmark$ & $\checkmark$ & $\checkmark$ \\
\hline Total Assets \% change & $\checkmark$ & $\checkmark$ & $\checkmark$ & $\checkmark$ \\
\hline Loan Portfolio \% change & N/A & N/A & N/A & N/A \\
\hline PAR 30 & N/A & N/A & N/A & N/A \\
\hline
\end{tabular}

\begin{tabular}{|l|c|c|c|c|}
\hline \multicolumn{5}{c}{ Top 325 Emerging Market Commercial Banks } \\
\hline Paramter tested & S\&P 500 & MSCI World Index & MSCI EM Index & Domestic GDP \\
\hline NOI & $\checkmark$ & $\checkmark$ & $\checkmark$ & $\checkmark$ \\
\hline ROE & $\checkmark$ & $\checkmark$ & $\checkmark$ & $\checkmark$ \\
\hline Profit Margin & $\checkmark$ & $\checkmark$ & $\checkmark$ & $\checkmark$ \\
\hline Total Assets \% change & $\checkmark$ & $\checkmark$ & $\checkmark$ & $\checkmark$ \\
\hline Loan Portfolio \% change & $\checkmark$ & $\checkmark$ & $\checkmark$ & $\checkmark$ \\
\hline PAR 30 & $\checkmark$ & $\checkmark$ & $\checkmark$ & $\checkmark$ \\
\hline
\end{tabular}


Exhibit 8

Summary of Results - Statistically Significant Differences in Regression Coefficients

\begin{tabular}{|l|c|c|c|c|c|}
\hline \multicolumn{5}{|c|}{ MFIs vs. EMIs } \\
\hline Paramter tested & S\&P 500 & MSCI World Index & MSCI EM Index & Domestic Stock Index & Domestic GDP \\
\hline NOI & $\checkmark$ & $\checkmark$ & $\checkmark$ & & \\
\hline ROE & & & $\checkmark$ & & \\
\hline Profit Margin & & & $\checkmark$ & & \\
\hline Total Assets \% change & $\checkmark$ & $\checkmark$ & $\checkmark$ & N/A & \\
\hline Loan Portfolio \% change & N/A & N/A & N/A & N/A & N/A \\
\hline PAR 30 & N/A & N/A & N/A & & \\
\hline
\end{tabular}

\begin{tabular}{|l|c|c|c|c|c|}
\hline \multicolumn{5}{|c|}{ MFIs vs. EMCBS } & Domestic GDP \\
\hline Paramter tested & S\&P 500 & MSCI World Index & MSCI EM Index & Domestic Stock Index & \\
\hline NOI & $\checkmark$ & $\checkmark$ & & & \\
\hline ROE & $\checkmark$ & $\checkmark$ & $\checkmark$ & & $\checkmark$ \\
\hline Profit Margin & $\checkmark$ & $\checkmark$ & $\checkmark$ & & \\
\hline Total Assets \% change & $\checkmark$ & $\checkmark$ & $\checkmark$ & & \\
\hline Loan Portfolio \% change & $\checkmark$ & $\checkmark$ & $\checkmark$ & & \\
\hline PAR 30 & $\checkmark$ & $\checkmark$ & $\checkmark$ & \\
\hline
\end{tabular}

MFIs significantly less sensitive

EMIs / EMCBs significantly less sensitive 